\title{
Villagers' Satisfaction Indicators on Village Information System in The Front Region
}

\author{
Harapan Tua Ricky F S, Syofian \\ Fakultas Ilmu Sosial dan Ilmu Politik, Universitas Riau \\ e-mail: harapan.tua@ lecturer.unri.ac.id
}

\begin{abstract}
This research aims at describing the process of services implementation through village information system based web and the villagers' satisfaction from the aspects of satisfaction standardization. The method of the research was qualitative with hermeneutic phenomenology approach. It would see the texts of villagers' life and experiences in using Village Information System Services. The data were analyzed by using van kaam model. It was found that service satisfaction of village information system in the context of individual experience identified from the staffs' attitude, information, delivery, internal manager's role, and time service accuracy. Based on the finding, it is recommended for the further researcher to conduct a study about the service implementation as well as e-government. The weakness of this research is that researcher conducted it in short time asking the individual's experiences about the village service information system implementation.
\end{abstract}

Keywords: Service, Individu, Information, Village Government, Villagers, Satisfaction

Abstrak

Tujuan penelitian Penentu kepuasan warga desa dalam menerima layanan Sistem Informasi Desa di kawasan Pulau Terdepan Terluar adalah melihat proses pelayanan yang dilaksanakan melalui sistem informasi desa dan melihat kepuasan warga desa dari identifikasi kepuasan warga desa dari aspek-aspek standar kepuasan. Metode penelitian yang digunakan dengan jenis kualitatif dengan pendekatan fenomenologi hermeneutik karena ingin melihat teks-teks kehidupan dan pengalaman hidup warga desa yang mengunakan Sistem Informasi Desa untuk menerima pelayanan di desa. Analisis data mengunakan model Van Kaam. Hasil penelitian menujukkan bahwa kepuasan pelayanan sistem informasi desa yang ada pada masyarakat desa dilihat dari konteks pengalaman individu informan terindentifikasi dari aspek Sikap Aparatur, Informasi, Delivery, Peran Internal Manager, dan Ketepatan Waktu Pelayanan. Kontribusi hasil penelitian ini dapat ditindak lanjuti dari segi pelayanan dan kebijakan penggunaan egovernment Kedepannya. Kelemahan penelitian hanya dilakukan dengan waktu singkat dan menanyakan pengalaman individu-individu penerima layanan sistem informasi desa.

Kata Kunci : Pelayanan, Individu, Informasi, Pemerintahan Desa, Warga Desa, Kepuasan

\section{INTRODUCTION}

Village as a basic public organization institution in the level of administration spearheaded the development and enhancement of community welfare. It is mentioned in the Consitution No. 6, 2014, about village. This policy expected on village development and the rural development in the both social and economical aspects. It aimed at competitiveness improvement towards the strong country concept.

It started from the concept of development "develop a village with top-down policy principle and a village develops with bottom-up policy principle" which meant that country develop a village. The development of concept village-developing in the process of village policy implementation is determined 
by the institutional improvement of the village which based on its own local potency. In 2017, Riau government said that village budget use achieved $79 \%$ from Rp. 808.148.380.748. It means that only 1.06 $\%$ used for developing the economical potency and $2.90 \%$ used for empowering the community.

The achievement of local village fund use in 2017 of Riau Province leaded developing a village concept with a different quantity of budget from the previous policy. It was expected that the policy will bring the village into the independent village by using budget from the business profit, assets, donation, and local village revenue. So, it will develop Indonesia.

The changing of this policy related to the villagers' expectation for getting qualified services from the local village government. The orientation of public policy is public services implementation because the output of a policy is about government action for community in both of product and service implementation. In line with the policy development of village government implementation, government through Ministry of Home Affairs Regulation No. 2, 2017, about minimal services standardization clearly managed that village government implementation related to service implementation has an important part of government and should be implemented well by the local village government. Village service in several regions of Java Island especially in West Java have adapted and followed the information and communication technology development as well as Village Information System and Village Digitalization.

Village Information System which is built in villages brings hope for the vilages in front area to get wide access and give qualified services for the public (Shidende, 2014). One of the villages which implemented Village Information System in front area of Bengkalis is Teluk Lecah Village, district Rupat. Village Information System implemented in Teluk Lecah is web based system developed by Village Government. It aims to improve the service effectively and efficiently and assisting the staffs' job (Setiawan \& Mahendra, 2015).

The implementation of this program eases the villagers and government to access and share information quickly and local village government service implemented effectively and efficiently so it can satisfy the community (Hildawati, 2019). This program conducted by the action of village building based Information and Communication Technology by optimalizing Village Information Systmen and Village Internet. This far, the lack of insfrastructures of ICT and human resources affect the implementation process of village information system service based web. Unfortunately, insfrastructures of ICT and human resources are the main factors of reliability, empaty, responsive and communicative public service implementation.

Determaining the quality of service is not always influenced by insfrastructures and facilities, capability and skills, but also by the quality of services given by the staffs (Yusrizal, Heriyanto, \& Harapan, 2018). For realizing it was also influenced by the stakeholder's leadership (Hariana \& Harapan Tua, 2016) and service innovation in order to get the qualified service (Ilham \& Harapan, 2016).

There were several problems found in implementing innovated services based ICT in Teluk Lecah Village. First, it has lack of data and information to be shared to the community. According to Lanin \& Hermanto (2019), developing public's trust can be done by improving giving, time accuracy of service, information availability, staff profesionalism, the number of staff, external and internal manager, and minimalizing political organization of local government. Second, uneffective smartphone usage by the people. Local village government staffs and community prefer to see social media to information provided in the village web. Based on this phenomenon, an action conducted for the target as the indicators of villagers' satisfaction on information system service implementation in the Front Region. 


\section{METHOD}

This research conducted in Teluk Lecah Village, Rupat District, Bengkalis Region. This Village is one of the front area villages with the implementation of Village Iinformation System Based Web. The method of this research was qualitative with hermeneutic phenomenology approach (Sudarsyah, 2016). The aim of this study is to see the texts of villagers' life and experiences in using the Village Information System Services. The instruments of the research were observation, social media interaction, documentation, and deep interview to the respondents. The informan of the research were villagers and local village government staffs. The data were analyzed by using Van Kaam model (Moustakas, 1994). It used for describing and interpreting the phenomenon related to the implementation of Village Information System Service in facing Revolution Industry 4.0 era with focus on indicators of villagers' satisfaction of Village Information System Service implementation in front island.

\section{FINDING AND DISCUSSION}

This research was conducted based on the related findings of previous research. It was about the service quality and villagers' belief. It said that villagers' belief was started from the services they got (Sari, 2017). Besides that, it is assumed that belief in public service implementation will increase as well as giving development, time service accuracy, information availability, professionalism of the staffs, the number of the staff, external and internal manager, and minimalizing political organization (Lanin \& Hermanto, 2010). Quality determines public's satisfaction and based on the service target perceptions. Service should be tangible, realibility, responsiveness, assurance, and well emphaty. Service will be better if there is a well organized commitment between organization and strategy orientation (Andrews, Boyne, Law, \& Walker, 2011). Then, in implementing service based e-government, it should be government based web empowerment and utilized well in the process of governement and public service implementation (Eviana Septiana Rachman, 2017).

Public service in the revolution industry 4.0 for the Village Government level is appropriate to the Milenium Global Village-Net (MGV-Net) demands. It must be supported by the villagers. It helps the villagers to get information through smartphone. So, the service implementation will be effective and efficient (Astuti et al., 2016). Based on the finding, there was a problem found related to the data service, human resources, and tools of sharing information. It finaly influenced the villagers' satisfaction index. The lack of local village government staffs and villagers' ability in operating the system made the service run unnaffective. It should be avoided because the effectiveness of service implementation by using system will achieve the public service effectiveness standardization (Marlinda, 2017). In fact, effort expectancy and Social Influences in service based web implementation affected users' service motivation (Susanto, 2015).

Transparency is one of the service satisfaction indicators for the service users. Accountability develops the service users' belief. System used in service implementation should be improved the quality because it determines the success of service implementation with good governance principles (Nasution, 2018). In addition, the government has an important role in public service implementation. Village internet is a new challenge for local village government in implementing public service. It will change the youth's mind as the further government administrator.

In providing service, public service sector has an obstacle related to central government, budgeting, and stakeholders' participation. Noviyanto, Setiyadi, \& Wahyuningsih (2014) say that fruitfulness of service will be effective and efficient if it is utilizing mobile technology. It is expected that by using mobile technology, the government can be empowered so the village information system 
implementation will run effectively and efficiently. At last, process of information system based ICT will produce a social process in rural community.

Based on the previous research and this research finding, it is found that public belief in government created public trust to public sector and social institution because the public service does not run competitively and commercial implementation aspect is not too relevant in public service (Fowler dan Pryke, 2003). When public community thinks that government cannot be responsible, public belief will decrease automatically. Villagers' satisfaction produces belief to government, poll, political efficacy and political participation. Then, it produces community welfare. Unfortunately, the people do not realize it.

This research finding was about service satisfaction indicators accepted by target community of sevice implementation. They were staffs' attitude, information, information sharing, internal manager role, external manager role, local politics, and service time consuming. These findings will be described clearly as following.

a. Staffs' Attitude

It was found that staffs had attitude such as friendly, honesty, symphaty, and non-discriminative in offering service to the villagers. Mori and Thomson (2004) say that staffs' attitude determines the villagers' satisfaction on the service. Besides that, Parasuraman et al (1990) also say that service quality can be indicated by the service provider as well as staffs. These indicators can be the language used, politeness and responsibility, and empathy. It means that service providers should serve the community in fair and politely because they wanted to be accepted and respected when coming to the public service institution. Chen et al (2012) say that public satisfaction will decrease along the discriminative attitude offered by the staffs. In the othe words, public sevice provider should be presented both fairness and politeness because they influenced public satisfaction (Chang, 2008).

b. Information

Village Information System based web at Village Teluk Lecah, Rupat Island, can be guidance for other villages in implementing this system. It is very important to provide accurate and detailed information to villagers in order to improve public satisfaction (Yuan and Chu, 2013). In this research, information indicated the public satisfaction on service. In this case, information deals with information as the solution and information provided about the public service improvement. There are several indicators of public service implementation. They are service procedure, budget, time, information service availability, and information accuracy and information quality (Saha et al, 2012).

Nowaday, Social media is an effective instrument for government in sharing information related to public service (Criado et al, 2017). Unfortunately, this research finding says that there were poor connection and low information access occurred when villagers wanted to use information system based web. It caused frustration and anger of villagers especially the young generation in the rural area. In another word, social media did not work yet effectively for sharing information in village.

c. Service Delivery

Service delivery is an important indicator of villagers' satisfaction based on the result, service provider's capability to satisfy target, and problem-solving method used by the service provider. This research findings shows that copying information had a great role in satisfying the public. In this case, information based web is an indicator of information sharing achievement. In fact, it was found that administration service run manually. Information delivery had a big affect on public satisfaction. It states that the key of public satisfaction improvement in public service is offering a good service and understanding the public needs (Amoako, 2012). It will motivate the villagers to have a wise expectation on public service.

d. Internal Manager Role

Village officer and village secretary was the internal manager. They determined the villagers' satisfaction in having the village information system service. Village officer could instruct the staff, 
delegate authority, dissemination, searching and receiving information from the staff, allocate resources and resolve the internal problem. Denhardt (2013) says that internal manager motivation leads the staff improve their productivity.

This research finding shows that recently the staff of local government had no responsibility on public service satisfaction. It caused by the lack of motivation as well as incentive they got. Fowler and Pryke (2003) state that social welfare in implementing the public service influence the service poliy and decision of service provider. Implicitly, it can be concluded that manager role in internal organization will determine the staffs' performance and productivity. It finaly creates a service quality and villagers' satisfaction.

\section{e. Service Time Accuracy}

Public service should be handled in quick and reasonable time. The accuracy of time is defined as the quality and being on time service. In this research, time accuracy is a key instrument for public service satisfaction. It was presented by several indicators. They were the length time used in conducting service and how the staffs communicated to the villagers during the service. It was found that quick service influence the public satisfaction. It is similar to responsive concept used.

Based on the responsive concept, both public service provider's response and speed are the indicators of public service evaluator. Eventhough the quick response is the main priority, durability, performance, and error also influence the quality of the service. The researcher found that there were some villagers used the service incidentally. It was not a structured administration. So, Village Service System implementation was limited for youth users in Teluk Lecah.

\section{CONCLUSION}

Based on the findings, it can be concluded that public service provided by the local village government especially village information system based web as well as e-government will improve the villagers' satisfaction on the basic needs such as population administration. Besides that, local village government must improve the staffs' attitude in implementing the service, information availability, information delivery, and internal manager role to support the quality and accuracy of the service implementation. The public satisfaction improvement on the basic service implementation will increase the public beliefe on the local village governmet.

This study has a theoretical and practical implication. Information system service based web reconstructed new service model contributed to local village service management improvement. This model leads the villagers to observe the information development in an organization related to the villagers' satisfaction. For the further researcher, it should be conducted a study of the villagers' belief on the government contributes to political efficacy, participation politic and social welafere necessity. The further researcher needs to focus on the internal sector of government and involving new variables such as professionalism, public satisfaction, political participation, and social welfare.

Practicaly, this research finding presents the village information system service management for local village government to provide information system towards the community development and empowerment. Both services are the local village government responsibility in facing revolution industry 4.0 era of the outonomy government system.

Villagers' satisfaction on the service implementation influenced the level of satisfaction to the local village government. Village Information System based web will assists the local village government in implementing the qualified service and having the villagers' belief 


\section{SUGGESTION}

Based on the research finding, the researcher suggest the local village government to improve the information service content, staffs' attitude, and staffs' capability and skill supported by the internal manager so the accuracy and quality of service implementation can be achieved. Villages in the front island are hard to cover so village information system based web is the best solution. Finaly, it should be stated that local village government must implement the service based information system by preparing the qualified staffs and facilities.

\section{BIBLIOGRAPHY}

[1]. Afrizal, D., Effendi, N., \& Handayani, P. (2019). Upaya Pemberian Pelayanan Publik Di Upt Puskesmas Balai Makam Kabupaten Bengkalis. Jurnal Niara, 12(1), 69-78. https://doi.org/10.31849/nia.v12i1.2331

[2]. Aguswan, A. (2017). Sistem Informasi Pelayanan Publik Dikecamatan Kampar Timur Kabupaten Kampar. Jurnal Niara, 10(1), 30-35. https://doi.org/10.31849/nia.v10i1.1886.

[3]. Amoako, I.O. (2012), "Trust in exporting relationships: the case of SMEs in Ghana", DProf thesis, Middlesex University, London.

[4]. Andrews, R., Boyne, G. A., Law, J., \& Walker, R. M. (2011). Strategy implementation and public service performance. Administration and Society, 43(6), 643-671. https://doi.org/10.1177/0095399711412730.

[5]. Andrews, D. and Turner, S. (2017), "Improving the customer experience through consistency and effective service delivery in the United Kingdom public house sector", British Food Journal, Vol. 119 No. 3, pp. 587-599.

[6]. Astuti, W., Irawati, I., \& Ruslihardy, R. (2016). Kualitas Pelayanan Publik Pada Kantor Camat Tenayan Raya Kota Pekanbaru. Jurnal Niara, 9(1), 29-36. https://doi.org/10.31849/nia.v9i1.2015

[7]. Chang, J.J.S. (2008), "An analysis of advance fee fraud on the internet", Journal of Financial Crime, Vol. 15 No. 1, pp. 71-81.

[8]. Chen, S.C., Yen, D.C. and Hwang, M.I. (2012), "Factors influencing the continuance intention to the usageofWeb2.0:anempiricalstudy”,ComputersinHumanBehavior,Vol.28No.3,pp.933-941.

[9]. Criado, J.I., Rojas-Martin, F. and Gil-Garefa, J.R. (2017), "Enacting social media success in local public administrations: an empirical analysis of organizational, institutional, and contextual factors", International Journal of Public Sector Management, Vol. 30 No. 1, pp. 31-47

[10]. Di, K., \& Pasirjambu, K. (2017). Kualitas pelayanan publik bidang administrasi kependudukan di kecamatan pasirjambu. JIMIA, 11(2), 56-65.

[11]. Erlianti, D., \& Sari, N. I. (2019). Analisis Akuntabilitas Pelayanan Kantor Lurah. 12(1), 35-45. 
[12]. Eviana Septiana Rachman, B. N. (2017). Pemanfaatan e-government pada desa wonokarto untuk meningkatkan akurasi dan informasi potensi desa. Jurusan Sistem Informasi STMIK Pringsewu Lampung Jl. Wisma Rini No.09 Pringsewu E-Mail: Evianaseptianar@gmail.Com Bhenipamungkas@gmail.Com Abstrak,8(1),45-50.

[13]. Fowler, A. andPryke, J. (2003), "Knowledge management in public service provision: the child support agency", International Journal of Service Industry Management, Vol. 14 No. 3, pp. 254283.

[14]. G4S Assessment Service UK (2009), "Public service", available at: $\underline{w w w . g 4 s}$ assessment service.com (accessed February 3, 2015).

[15]. Hariana, \& Harapan Tua, R. F. . (2016). Kepemimpinan Kepala Desa Dalam Pembangunan Fisik Desa Kota Intan Kecamatan Kunto Darussalam Kabupaten Rokan Hulu. JOm Fisip, 3(2), 1-14.

[16]. Hawi, R., Alkhodary, D. and Hashem, T. (2015), "Managerial companies and organizations performance", International Journal of Management Sciences, Vol. 5 No. 11, pp. 723-735

[17]. Harsini, H. (2018). Transparansi Pelayanan Publik Pada Dinas Penanaman Modal Dan Pelayanan Terpadu Satu Pintu (Dpmptsp) Kota Pekanbaru. Jurnal Niara, 10(2), 65-71. https://doi.org/10.31849/nia.v10i2.1903

[18]. Hernimawati, H., \& Sudaryanto, S. (2018). Peran Pemimpin Dalam Pelayanan Publik Di Kantor Camat Xiii Kota Kampar Kabupaten Kampar. Jurnal Niara, 10(2), 96-105. https://doi.org/10.31849/nia.v10i2.1907

[19]. Herrala, M. E., \& Haapasalo, H. J. O. (2012). Effect of governance models on enhancing water service delivery. International Journal of Public Sector Management, 25(5), 373-390. https://doi.org/10.1108/09513551211252396

[20]. Heryenzus, H., \& Suali, S. (2018). Pengaruh Kinerja Pelayanan Dengan Pendekatan Malcolm Baldrige Terhadap Kepuasan Pasien Bpjs Kesehatan Pada Rumah Sakit Umum Daerah Kota Batam. Jurnal Niara, 11(2), 150-158. https://doi.org/10.31849/nia.v11i2.2112

[21]. Hildawati. (2019). Indeks Kepuasan Masyarakat (Ikm) Dalam Pelayanan Sim Pada Satlantas Polres Dumai. Jurnal Niara, 12(1), 86-99. https://doi.org/10.31849/nia.v12i1.2641.

[22]. Iberahim,H.,MohdTaufik,N.K.,MohdAdzmir,A.S.andSaharuddin,H.(2016), “Customersatisfaction on reliability and responsiveness of self-service technology for retail banking service", Procedia Economics and Finance, Vol. 37, pp. 13-20.

[23]. Ilham, \& Harapan, T. R. F. . (2016). Inovasi Palayanan Dalam Pengurusan Pajak Kendaraan Bermotor pada UPTD Samsat Kota Bukit Tinggi. JOm Fisip, 3(2), 1-20.

[24]. Kanter, A. S., Negin, J., Olayo, B., Bukachi, F., Johnson, E., \& Sachs, S. E. (2009). Millennium Global Village-Net: Bringing together Millennium Villages throughout sub-Saharan Africa. International Journal of Medical Informatics, $\quad 78(12), \quad 802-807$. https://doi.org/10.1016/j.ijmedinf.2009.08.002 
[25]. Kanungo, S. (2004). On the emancipatory role of rural information systems. Information Technology \& People, 17(4), 407-422. https://doi.org/10.1108/09593840410570267

[26]. Kurniati, R., Jaroji, J., \& Agustiawan, A. (2018). Sistem Layanan Mandiri Di Kantor Desa Berbasis Web. INOVTEK Polbeng - Seri Informatika, 3(1), 16. https://doi.org/10.35314/isi.v3i1.326.

[27]. Kurniawan, J.L. and Puspitosari, H. (2007), Wajah buram pelayanan, Malang Corruption Watch, Malang.

[28]. Lamharhar, H., Chiadmi, D., \& Benhlima, L. (2014). How semantic technologies transform egovernment domain. Transforming Government: People, Process and Policy, 8(1), 49-75. https://doi.org/10.1108/tg-07-2013-0023

[29]. Lanin, D., \& Hermanto, N. (2019). The effect of service quality toward public satisfaction and public trust on local government in Indonesia. International Journal of Social Economics, 46(3), 377-392. https://doi.org/10.1108/IJSE-04-2017-0151.

[30]. Madumo, O.S. (2014), "Fostering effective service delivery through public participation: a South African local government perspective", Association of Teacher in Public Administration, Vol. 22 No. 3, pp. 130-147.

[31]. Marlinda, P. (2017). Efektivitas Partisipasi Masyarakat. 10(1), 36-44.

[32]. Mori and Thomson, W. (2004), "Customer satisfaction with key public services", available at: www.cabinetoffice.gov.uk/opsr (accessed Agustus 04, 2019).

[33]. Moustakas, Clark. (1994) Phenomenological Research Methods, California: SAGE,

[34]. Munari, L., Lelasi, F. and Bajetta, L. (2013), "Customer satisfaction management in Italian banks", Qualitative Research in Financial Markets, Vol. 5 No. 2, pp. 139-160.

[35]. Nasution, S. R. (2018). Penerapan Prinsip-Prinsip Good Governance Dalam Pelayanan Publik Di Kantor Camat Sail Kota Pekanbaru. Jurnal Niara, 10(2), $72-77$. https://doi.org/10.31849/nia.v10i2.1904.

[36]. Napitupulu, P. (2007), Pelayanan publik dan customer satisfaction, Alumni, Bandung.

[37]. Noviyanto, F., Setiyadi, T., \& Wahyuningsih, I. (2014). Implementasi Sikades (Sistem Informasi Kependudukan Desa) Untuk Kemudahan Layanan Administrasi Desa Berbasis Web Mobile. Informatika, 8(1), 858-869. https://doi.org/10.26555/JIFO.V8I1.A2084.

[38]. Parasuraman,A.,Berry,L.L.andZeithaml,V.A.(1991), "Perceivedservicequalityasaconsumer-based performance measure: an empirical examination of organizational barriers using an extended service quality model”, Human Resource Management, Vol. 30 No. 3, pp. 335-364.

[39]. Parasuraman, A., Zeithaml, V.A. and Berry, L.L. (1985), "A conceptual model of service quality and its implications for future research", Journal of Marketing, Vol. 49 No. 4, pp. 41-50. 
[40]. Parasuraman, A., Zeithaml, V.A. and Berry, L.L. (1988), "SERVQUAL: a multiple-item scale for measuring consumer perceptions of service quality", Journal of Retailing, Vol. 64 No. 1, pp.14-40.

[41]. Parasuraman, A., Zeithaml, V.A. and Berry, L.L. (1990), "Five imperatives for improving service quality”, MIT Sloan Management Review, Vol. 31 No. 4, pp. 29-38.

[42]. Parasuraman, A., Zeithaml, V.A. and Berry, L.L. (1994), “Alternative scales for measuring service quality: a comparative assessment based on psychometric and diagnostic criteria", Journal of Retailing, Vol. 70 No. 3, pp. 201-230.

[43]. Rahmawati, D. (2013), "Pengaruh motivasi terhadap produktivitas kerja karyawan PR Fajar Berlian Tulungagung", Jurnal BONOROWO, Vol. 1 No. 1, pp. 1-15.

[44]. Salman, A. A., Mostert, J., \& Mugwisi, T. (2018). The governance and management of public library services in Nigeria. Library Management, 39(6-7), 389-401. https://doi.org/10.1108/LM08-2017-0075.

[45]. Saha, P., Nath, A.K. and Salehi-Sangari, E. (2012), "Evaluation of government e-tax websites: an information quality and system quality approach", Transforming Government: People, Process and Policy, Vol. 6 No. 3, pp. 300-321.

[46]. Salminen, A. and Ikola-Norrbacka, R. (2010), "Trust, good governance and unethical actions in Finnish public administration”, International Journal of Public Sector Management,Vol.23No.7, pp. 647-668.

[47]. Saputra, T., Marlinda, P., Sufi, W., \& Kuning, U. L. (2019). Implementasi Kebijakan Inovasi Pelayanan Publik. 11(2), 177-184.

[48]. Saputra, T., Utami, B. C., \& Sufi, W. (2018). Pengaruh Persepsi Mahasiswa Terhadap Kualitas Pelayanan Pegawai Dibagian Administrasi Fakultas Ilmu Administrasi Universitas Lancang Kuning. Jurnal Niara, 11(1), 6-16. https://doi.org/10.31849/nia.v11i1.1520

[49]. Sari, W. P. (2017). Analisis penerapan e-government dan perubahan interaksi sosial setelah mediatisasi di desa karang bajo, Lombok. THe Messenger, 9, 176-185.

[50]. Setiawan, D., \& Mahendra, Y. A. S. (2015). Perancangan Sistem Informasi Penduduk Pada Kantor Desa Kebonsari. IJNS - Indonesian Journal on Networking and Security, 4(2), 21-26. https://doi.org/10.1123/ijns.v4i2.1309

[51]. Shidende, N. H. (2014). Challenges in implementing patient-centred information systems in Tanzania: An activity theory perspective. Electronic Journal of Information Systems in Developing Countries, 64(1), 1-20. https://doi.org/10.1002/j.1681-4835.2014.tb00455.x

[52]. Subiakto, H. (2013). The usage of internet for the village and villagers. Masyarakat, Kebudayaan Dan Politik, 26(4), 243-256. Retrieved from http://journal.unair.ac.id/download-fullpapersmkpa4d7ec1aaefull.pdf 
[53]. Sudarsyah, A. (2016). Kerangka Analisis Data Fenomenologi (Contoh Analisis Teks Sebuah Catatan Harian). Jurnal Penelitian Pendidikan, 13(1).

[54]. Sufi, W., \& Herlinda, D. (2017). Penerapan Sistem Aplikasi Pelayanan Kepegawaian (Sapk) Berbasis Online Pada Badan Kepegawaian Daerah Kota Pekanbaru. Jurnal Niara, 9(2), 102-108. https://doi.org/10.31849/nia.v9i2.2103

[55]. Susanto, A. (2015). Faktor-Faktor Yang Memengaruhi Perilaku Penggunaan Internet Masyarakat Desa Pasar Vi Kualanamu, Deli Serdang Sumatera Utara Factors Affecting The Behaviour Of Internet Use Of Villager Pasar Vi , Kualanamu, DELI SERD. Jurnal Penelitian Pos Informatika, 5(1), 65-86. https://doi.org/10.17933/jppi.2015.050100

[56]. Utomo, D., Mulyanto, E., \& Kunci, K. (2010). Electronic Government Pemberdayaan Pemerintahan Dan Potensi Desa Berbasis Web. Jurnal Teknologi Informasi, 6(1), 1414-9999. Retrieved from http://pps.dinus.ac.id.

[57]. Vigoda-Gadot, E. (2006), “Citizens' perceptions of politics and ethics in public administration: a five-year national study of their relationship to satisfaction with services, trust in governance, and voice orientations", Journal of Public Administration Research and Theory, Vol. 17 No. 2, pp. 285305.

[58]. Yuan, X. and Chu, K. (2013), "When and how information quality matters: perceived customer orientation and customer satisfaction", Advance in Information Sciences and Service Sciences, Vol. 5 No. 9, pp. 105-113.

[59]. Yusrizal, Heriyanto, M., \& Harapan, T. R. F. . (2018). Pada Pelayanan Kartu Tanda Penduduk Elektronik ( KTP-el ). Jurnal Administrasi Negara, 15(1), 96-103. 